\title{
Critical Analysis of Press Freedom in Nepal after the Peace Agreement 2006
}

\author{
Binod Kumar Paudel \\ Institute of Communication Studies, Communication University of China, Beijing, China \\ Email:bnpaul20@gmail.com,bpaudel@fsu.edu
}

How to cite this paper: Paudel, B. K. (2017). Critical Analysis of Press Freedom in Nepal after the Peace Agreement 2006. Advances in Journalism and Communication, 5, 218-235.

https://doi.org/10.4236/ajc.2017.54013

Received: July 5, 2017

Accepted: October 16, 2017

Published: October 19, 2017

Copyright $\odot 2017$ by author and Scientific Research Publishing Inc. This work is licensed under the Creative Commons Attribution International License (CC BY 4.0).

http://creativecommons.org/licenses/by/4.0/

\begin{abstract}
A decade long civil war ended with a Comprehensive Peace Agreement (CPA) in 2006. To address the political developments, the Interim Constitution was promulgated in 2007. Though the Interim Constitution of Nepal 2007 guarantees press freedom, every year various incidents of press freedom violation are recorded by various national and international organizations. This article evaluates the situation of press freedom in Nepal since the signing of CPA 2006 by analyzing all the incidents of press freedom violation from 2007 to 2014 as recorded by International Federation of Journalists (IFJ). The analysis of those events shows lack of sufficient evidence and information to justify them as the press freedom violation. No matter where and how the journalist or media owner is killed, threatened or harmed physically, it is termed as press freedom violation. The situation of Press freedom after peace agreement in 2006 is not that critical as projected in various reports and there is no government censorship in media. However, if the mechanism by which press freedom violation cases are recorded could be reviewed and more details are included, those reports will be much reliable. This tendency of reflecting critical situation of press freedom by projecting every incident without an adequate investigation might deviate from other issues related to journalist's profession and further it might not motivate journalist and media to adhere to the code of ethics and become responsible to their profession. Though, the issue of professional safety of journalists could not be ignored, not all the incidents related to journalist are the cases of press freedom violation.
\end{abstract}

\section{Keywords}

Press Freedom, Censorship, Journalist Safety, Nepal

\section{Introduction}

The concept of press freedom is a contentious one in the literature of mass 
communication. Traditionally, media and political scholars have suggested that freedom of press in any given society is a function of the relevant country's political ecology (Himelboim \& Limor, 2008). The initial idea of press freedom first evolved as a component of the libertarian social philosophy which originated in England after the revolution of 1688 (Siebert et al., 1963). This idea focused primarily on freedom from government control. Lowenstein (1970) argued that "A completely free press is one in which newspapers, periodicals, news agencies, books, radio and television have absolute independence and critical ability, except for minimal libel and obscenity laws. The press has no concentrated ownership, marginal economic units or organized self-regulation." (cited in Becker, Vlad, \& Nusser, 2007). Traditionally press freedom is addressed in political terms as derived from the nature of the governing authorities and from the relations between political and media institutions. More recent critics have shifted the focus towards economic and financial aspects of media organizations, viewing them as a threat to media freedom (Himelboim \& Limor, 2008).

The concept of Press Freedom is notably possessed to the western society, greatly the United State and some other country at the beginning but now it is the necessity of each and every democratic country around the world. The practice of freedom of press is not same around the world which is reflected in the freedom house report. As mass media is the best instrument for the society to exercise its right to freedom of expression, its freedom gives the reflection of the country in terms of free expression.

In case of Nepal, any activity that opposes the constitutional provision related to freedom of expression and specific articles related to media could be termed as the violation of Press Freedom.

Historically, the practice and aim of press freedom is seen changing as per the change in political system. During the pre-democratic period (Rana Regime), the practice was guided by the authoritarian system. But after the establishment of democracy in 1950, press freedom was ensured through the constitutional provision of Freedom of Expression in the Interim Constitution of 1951. Though, limitations in implementation, the government has theoretically accepted the concept of Freedom of Expression as per article 19 of Universal Declaration of Human Rights which states "Everyone has the right to freedom of opinion and expression; this right includes freedom to hold opinions without interference and to seek, receive and impart information and ideas through any media and regardless of frontiers". So we can say press freedom is closely related with the political liberalization or the democratization and it is partly a reflection of on-going political as well as social changes around the world. Based on various political system, the issue of Press Freedom has shifted from classical liberal perspective i.e. freedom from Government control to radical democratic perspective in Nepal. During the autocratic period, the issue of Press Freedom was much concerned with free from government control and free from censorship. But after the restoration of democracy in 1990, it is focused towards the safety of journalists and towards ensuring the free flow of information. Due to the onset 
of civil war in 1996 and declaration of emergency in 2001, Nepalese media sector had to face difficult time. Immediately after the emergency of 2001, government came up with a virtual censorship order, issuing a set of do's and don'ts to the press (Kafle, 2003). The situation was much deteriorated after the royal coup in February 2005. The royal regime began its attack on independent media right from the time of announcement of royal takeover by sending security forces on media houses, radio and television stations (Gaunle, 2006). These affected the professional nature of media that was being institutionalized gradually before the Royal take over. Even the foreign newspapers entering Nepal were censored before they were distributed in the market, international news channels were strictly controlled and foreign online news services were controlled while many online services were blocked (Dahal, 2006).

All governments after 2006 have ensured total press freedom as per the constitutional provision, and the media have been free to criticize even the head of the government. But the Freedom House index shows Nepal as partly free country. The recent reports on press freedom reflect the concern of physical safety as the major problem on press freedom. Almost all the reports published after 2006 has mentioned about the deteriorating situation of Press Freedom though the incidents of violence against media varies year to year. It could be argued that the press freedom has been compromised since 2006 but there is no consistent increasing pattern in the number of incidents related to press freedom violation. Though there are substantial reports on press freedom situation, less has been discussed in relation to broader context of adequate investigation of such cases and analysis of complex social structure. This chapter is concerned with: what sort of events was recorded as the cases of press freedom violation? Are these cases/reports able to project the exact situation of Press Freedom in the changed context? Who is responsible in violating Press Freedom? To what extent we can ensure the constitutional provision of Press Freedom and create a safer working condition for Journalist and the media. By analyzing 273 cases of Press Freedom violation published in the annual report of International Federation of Journalists from May 2007 to April 2015, this chapter provides the various dimensions of press freedom in Nepal.

Beyond the constitutional guarantee, there are various obstacles on the road to freedom and these have resulted from lack of competence, financial insufficiency to run media, political affiliation, corporate interests, criminal interests, and all.

\section{Background}

Through Nepal's long and chequered history as an independent nation of the Himalayas, Nepal has many a time repulsed invasions from both the South (British India) and the North (Tibet/China) and has thus proved herself, in various respects, worthy of her national freedom and independent existence. But historical changes and developments in India and China/Tibet have left their mark on Nepal (The Economic Weekly, 1955). Media sector was not an exception in this regard. Publication of magazines/newspapers was learned/influenced 
from India (British India). The global wave of independence and liberalization has also influenced in Nepalese political environment. Taking the year 1990 as the reference year we can broadly categorize the period as pre 1990 and post 1990. The multiparty democracy was reinstated in 1990.

\subsection{Media Development and Journalists Role before 1990}

The history of press in Nepal actually begins with the revolution of 1950, even though some humble start was made before (Baral, 1975). The historical account suggests that the beginning of journalism or say the birth of journalists in Nepal (if we take into consideration ruling system) have been politically motivated where, media was considered as tool to support the dominant ruling elites, whereas opposition considered it to fight for democratic ideals (Bhuwan, 2014). Though literary in nature, Sudhasagar a privately owned magazine was the first to be published on July 1898 in Nepal. Few years later, publication of Gorkhapatra as a weekly newspaper started being the first state run media. The guidelines for publishing Gorkhapatra was not to write against the ruling Rana premier and the system (Bhuwan, 2014). There were in total 13 newspapers/magazines: 2 weeklies, 4 Fortnightly and 7 monthly, published before the establishment of democracy i.e. 1951 A.D. (synthesized from Devkota, 2002). Just few days before the establishment of democracy, publication of a weekly newspaper "Jagaran" started which was the only newspaper with political views at that time. Though, most of the papers were financially supported by the government (Devkota, 2002) they were unable to continue their publication. The oppositional group the political leaders, activists and literary writers who fought against the authoritarian regime, the freedom fighters were the predecessor of journalists of Nepal (Bhuwan, 2014). Function of journalists in this half century period (1901-1951) was to disseminate government notices and information (Malla, 1983: cited in Dahal 2013). So the pre-democratic period or the Rana regime period could be said as the beginning of democratic ideology phase where journalists favored the need of democratic system and wrote against the authoritarian system.

The Interim constitution of 1951, introduced after the end of Rana regime provided fundamental rights including freedom of speech (Dahal, 2011). According to Baral (1975), the first democratic period: 1950-60, was the period of rising aspirations when institutions were created, papers published and excessive enthusiasm shown by the people belonging to various walks of life. However, the relationship between the government and the journalists in this open democratic political system marked the tense relationship; democratic government blame journalists not being honest to perform advocacy role of the government decisions (Dahal, 2013). Compared to the number of papers registered in the first five decades of the twentieth century (a total of 16, including literary magazines), the number of papers registered in the decade after the overthrow of the Rana regime was large i.e. 264 (Parajuli, 2012). The majority of them were weekly newspapers and were mostly Kathmandu centric, few papers were published outside the capital. However, the newspapers at that time were less concerned 
about creating an informed society, rather they were pushing the agendas of particular groups or political ideologies (Dahal, 2002: cited in Banjade, 2007).

During Panchayat Era (1960-1990), government has restricted citizen's political freedom and the press freedom. Many newspapers were shut down in this authoritarian system. Journalists were obliged to either support the Panchayat system or close the operation of the news production (Dahal, 2013). We can say journalist during the Panchayat Era passed through partisan phase. However, the later years marked the partisan press along with the ideological division of journalists. Ideologically the journalists could be divided into three categories: supporter of democratic ideology, supporter of communist ideology and supporter of King (Bhuwan, 2014). The situation was relatively favorable as media's restriction was gradually replaced with Liberal Press and Publications related legal provision that removed most of the past restriction on the press after the referendum of 1980. By the end of Panchayet, the state run media like Gorkhapatra Daily, The Rising Nepal, Radio Nepal and Nepal Television were dominant. The non state media was confined to weekly newspapers owned by private individuals, most of whom were affiliated to one or another banned political party (Onta, 2001). The number of newspapers during the end of Panchayat has increased by about three times then it was in the beginning.

\subsection{Media Development and Journalists Role after 1990}

The restoration of multiparty democracy in 1990 was the remarkable achievement in terms of freedom of expression and press freedom. Constitution of Nepal 1990 guaranteed press freedom restricting the cancellation of newspaper registrations, censorship and newspaper closures. The oppositional weeklies of the Panchayet era were gradually eclipsed after 1993 by broadsheet dailies with relatively less ideologically inspired content (Onta, 2001). Other media outlets like Frequency Modulation (FM) radio, news portals, various private television stations were established in this period. However, the increase in the type of media outlets and number of media houses doesn't necessarily reflect the pluralism. Almost all major media in Nepal are the result of diagonal (conglomerate) ownership, with proprietors already having other businesses before venturing into the media business (Kharel, 2012).

Media were divided for and against the armed struggle resulting to affect independent reporting (Onta, 2006). Similar was the case with journalists. The root of this division is the practice of mission journalism and partisan press during the panchayet period.

The period after the restoration of democracy in 1990 could be termed as era of professionalism.

Journalism underwent a paradigm shift from 'mission journalism' to a profession mainly after the publication of the broadsheet dailies Kantipur and The Kathmandu Post 20 years ago (Bhattarai, 2013). This period marked the high partisan journalism in early 1990s and the introduction of professional and cor- 
porate interest journalism in Nepal, with journalists wanting to be away from the political units and be independent from the partisan culture and it still continues to be the same even today (Bhuwan, 2014).

The situation after the declaration of Emergency in 2001 adversely affected the media sector and journalists. The way of presenting news and issues was mostly affected by government directives and specifically by the Terrorist and Disruptive Acts (Control and Punishment) Ordinance (TADA) 2058 BS (2001). Report on the fight against Maoist "terrorism" were largely based on the information supplied by the Defense Ministry and other government sources (Kafle, 2003).

\subsection{Political Economy, Ownership and Role of Journalists}

Media ownership in Nepal is diverse in terms of numbers, types of media and ownership. Nepal has newspapers, magazines, radio stations, television channels, a news agency, cinemas, and an expanding online media. These media are variously owned by the government, private sector businesses and communities (UNESCO, 2013). The liberal policies after 1990 led the foundation for the increase of private investment and corporate media in Nepal. The study of Prajapati (2012) shows that ownership widely affects the issues of advertising especially when concerned media itself becomes a news event where media engages in propaganda to support its causes.

Though there was significant increase in the number and type of media after 1990 , it's difficult to see them as a media institution. Though owners claim media sector as an industry, they themselves are exploiting the journalist. Similar is the case with journalists. There is increase in the number of trained and educated journalists but it is difficult to say whether they are able to maintain their professional integrity and journalism is their only profession

\section{Legal Provisions Related to Media and Action Taken against Media}

\subsection{Before 1990}

Though Journalism was practiced since 1898, the royal decree called "Sanad" was issued giving the guidelines for what could and could not be published in Gorkhapatra. However, the first legal document to mention "Freedom of Press and Expression" was Government of Nepal Act 1948. Press Act, Chhapakhanara Prakashan Sambandhi Ain, enacted on 14 April 1948 prohibited the publication of a paper without first getting permission from the concerned authority of the state (Parajuli, 2012). The act specified the procedures for establishing a printing press and registering a newspaper. It also specified matters that were restricted for printing and publication. After abolishing Rana regime following the Delhi consensus, the interim constitution of Nepal 1951 was promulgated introducing Nepal to a new system of political governance (Parajuli, 2012). The interim constitution guaranteed freedom of speech with provisions related to freedom of expression and publication being stipulated in section 2, article 16(a). Following 
the interim constitution, two Acts, namely the Nepal Chhapakhanara Prakashan Registry Act 2008 and the Chhapakhanara Prakashan Sambandhi Act 2009 (BS), were introduced in 1952. Parajuli (2012) reveals the gradual shrinkage of press freedom envisioned by the Interim Constitution of Nepal 1951 through various legal provisions during the first democratic period from 1950-1960. His study shows the number of action taken against journalists/media also increased with the rise in the number of papers after 1951/52. During this period, 34 papers faced at least one type of action, collectively facing 100 actions in total.

After the declaration of Panchayet in 1961, Nepal reverted to autocratic rule having effect in the media sector too. The restrictions imposed on freedom put the press in an awkward situation after royal take over resulting to the closure (by losing the license to publish) of mouth piece of political parties and newspapers published with political motive in very early stage of Panchayet. In total 55 newspapers (10 dailies, 32 weeklies, 4 fortnightlies, 1 monthly, 5 bi-monthlies and 3 quarterlies) lost their licenses in 1962 for criticizing the government (Belbase \& Murphy, 1983). Though these were in accordance with the existing press laws at that time, it reflects the restricted press freedom during the period through censorship.

The Press and Publication act enforced in 1963 became controversial as well as determinant in harboring misgivings between the Press and the Government (Baral, 1975). The referendum in 1981 led to slightly liberalized press policies that allowed newspapers to publish alternative political views in the following decade, but no fundamental progress in the media took place until the restoration of the multiparty democratic system in 1990, which brought unprecedented freedom for the press (Neupane \& Zeng, 2014). According to Banjade (2007), Newspaper publication was not a business during the Panchayet system. Newspapers were known by publisher/editor and were basically a one-man show. The pre-1990 period could be termed as phase for mission journalism in Nepal. During three decade long Panchayet period various newspapers were suspended and banned, journalists were arrested and poisoned. The journalists were divided for and against Panchayet system.

\subsection{After 1990}

The constitutions of Nepal 1990, promulgated after the restoration of multiparty democracy guaranteed press freedom as a fundamental right. Constitutional provisions like: 1) No news/articles shall be censored 2) No press shall be closed or seized for printing any news item, article or other reading material 3) The registration of newspaper or periodicals shall not be cancelled merely for publishing any news item, article or other reading material provided a favorable environment to ensure press freedom. These provisions not only encouraged increasing investment in media but also increased the search for diverse source to finance it (Banjade, 2007). However, the onset of civil war in 1996 and emergency in 2001 affected the situation. Kafle (2003) gives the overview of the situa- 
tion media sector faced after the emergency in 2001. Few papers were unofficially barred from publication which was the violation of constitution and was rather done forcefully, with aggression, without any formal written notice against them. Arresting journalists, editors, publishers and/or workers in printing press, raid of media office, seizure of equipments like computer, telephone, printers etc from media office and printing press, seizure of newspapers occurred all over the country. Though such events could be justified for the sake of emergency, it has clearly breached the concept of press freedom envisioned in the constitution. Similar was the situation in Radio where they could not even air the news filed in by their own correspondents from the spot of event before confirming every news from the Army. More than one thousand (1000) journalists were rendered unemployment in the field of mass communication across the country till the end of king's direct rule in 2006 (Dahal, 2006). Even in the harsh situation of emergency, Mainali (2006) reveals that weekly newspapers were much intact in disseminating information and providing the opinion as compared to the broadsheet dailies. This shows the media sector that was trying to develop suffered a lot due to intensified suppression of press and journalists after the emergency till the April movement of 2006.

In summary, despite the restrictive environment in press, the level of press activity was high even before the referendum (Belbase \& Murphy, 1983) in panchayet period and during extreme risk of arrest, detention, beating and death of some colleague (Gaunle, 2006) after royal take over in 2005 reflecting the devotion towards the profession. Mainali (2006) identifies three actors responsible for censorship: State as the major actor, publisher/management as the second actor and journalist themselves as the third actor. Both the journalist and the media owner/management were affected during the period. Despite the state oppression, journalistic activities were intact.

\subsection{Post 2006 Scenario}

The direct rule of King ended after the protest led by political parties along with CPN (Maoist) who was fighting against the government. This further materialized the end of armed conflict through the Comprehensive Peace Agreement 2006. These political achievements were institutionalized for the time being through the Interim Constitution 2007. According to article 15 of Interim Constitution 2007, no publication, broadcasting or printing of any news items, editorials, features, article or other reading and audio-visual materials through any means whatsoever including electronic publication, broadcasting and printing shall be censored. Furthermore, Article 15 (2) protects any broadcasting, publishing or printing of material using radio, television, online or other types of digital or electronic equipment or medium from closure seizure or cancelation of registration because of such broadcasting, publication or printing. Considering the development in technology, the interim constitution recognized online media, which favored its growth. But due to lack of necessary amendment in media acts like Press and Publication Act, National Broadcasting Act online me- 
dia are treated in a different way than other (print and broadcast) media. Any disputes or complains related to online media are treated through Electronic transition Act which is heavily criticized and opposed by journalists. Working Journalist Act 2007 and Right to information Act 2008 were the significant achievement after the Interim Constitution. Yet the implementation of those acts is not satisfactory.

Due to favorable constitutional provision, awareness on the importance of media and the emergence of Maoist Party in the mainstream politics, the trend of opening new media houses increased heavily. The newspapers, supporting the Maoist party which were closed after the emergency started republishing. Besides, there was a hope of safe working environment for journalist and media houses. But the annual reports on press freedom reflect different picture. Though decline in number of recorded cases of press freedom violation, journalists are still facing harassment from political parties, local level officials and politicians, police and military force and criminal groups, especially when reporting on sensitive topics (Karleker \& Marchant, 2007). The news seems to be superficial and less investigative. Though limited to news on peace process, Adhikari (2008) reflects the reporting culture/trend as "Political dialogue, elections, restructuring and human rights have received sustained attention from the press, but coverage is almost always prompted by government and interest-group sponsored events, speeches and official trial balloons typical of the "he said/she said" construct."

\section{Politics and Debates of Press Freedom}

Press freedom is one of the aspects of overall media development through unrestricted access to information and mechanism to disseminate them. In the recent years, it not only focuses on free of government control but also free from the interest of corporate sector in any democratic country. However, the issue of Press Freedom seems to be raised and advocated relating to the government and to achieve political gain by both the journalists and political parties. Moreover, it's difficult to say the ongoing discussions on Press Freedom are for whom and for what purpose? Whether it is to enhance the democratic process by fulfilling the role of watchdog and creating informed society? Whether it is for journalists and media owners/entrepreneurs to perform their duty or for other people who are involved in journalism just to achieve progress in their other business and influence the decision making process. These issues are yet to be explored. The ongoing debate of press freedom seems to be limited with political gains and ensuring the benefit and interest of media owners but not for the journalists. The influence of corporate sector on media, the repression of journalists within their organization are relatively less discussed. The ongoing debate of limited perspective of Press Freedom seems to ensure the interest of media owners and some elites and political parties. However, this fails to ensure the institutional provisions and practice of free and responsible press and dignified life of jour- 
nalist. The struggle of journalists in different media houses for getting minimum wages for their work as prescribed by government and the reluctance of media owners to pay the minimum wages to their employee (journalists) arguing this as the violation of complete press freedom reflects the complex scenario ${ }^{1}$. If this practice continues, journalists seem to be the only looser affecting the people's right to know.

\subsection{Journalists as Political Party Members}

The affiliation of journalist with political parties has been institutionalized in Nepal. Various Journalists' associations are formed based on the ideological nearness with political parties. Though it's different in look, the root was from the very beginning of start of journalism. Though the journalists were ideologically close to political parties, they were organized with the concept of trade union after the restoration of democracy in 1990. The first of such association is Nepal Press Union, close to Nepali Congress established in 1991 May $27^{2}$. There are few studies related to political inclination of journalists and its influence in news. Pathak (2006) found that journalists affiliation to political party have had influence in reporting news. Bhuwan (2014) reveals journalists reporting on political affairs in major daily newspapers of Nepal are influenced by political ideology at personal level, but their affiliation to the political parties were significantly less. We can conclude that political ideology has influence on reporting of Nepalese journalists. Depending on the nature of media house, this affiliation could affect the news. For example, certain weekly newspapers, FM radios and Televisions are clearly visible whom they are supporting. Similar is the case with other employees in the media houses. Disputes between Journalists and media houses have been even reported based on the political affiliation. Due to this political affiliation the dispute of journalists and employees with media owner were easily deviated to get the political benefit and as a tool to get revenge with each other.

\subsection{Journalist Code of Conduct}

Press Council Nepal in co-operations of Federation of Nepalese Journalists has explained the duties of a journalist under the acting Code of Journalistic Ethics 2003. Every journalists practicing in Nepal are expected to follow media ethics in order to maintain professionalism. However, various studies shows lack of professionalism among journalists. Gautam (2008) identifies three major trends in Nepalese journalism after 1990: 1) The provision of pre-censorship has not only been used but its misused; 2) Right to Information is used by journalists and media houses as their own instead of common people; 3) It was institutionalized to remain silent over the weakness in media. Press Council Nepal is responsible to look after the issues on breaching code of conduct. As there are not any stu-

${ }^{1}$ http://www.mediakurakani.com/2016/05/07/know-why-media-owners-are-reluctant-to-implement -minimum-wage-for-journalist/

${ }^{2}$ http://nepalpressunion.org.np/ne/pages.php?pag_ID=29\&pae_ID $=111$ 
dies looking at the code of conduct and press freedom in Nepal, it's difficult to relate them. However, obeying the journalist code of conduct will definitely makes journalist much responsible, improve the quality of journalism, and could maintain trust. Further, there are not the cases of any threat or attack on journalists who are presenting serious investigative reports related to corruption with the name of associated people. The practice following journalist code of conduct will be able to resolve such traditional problems on media and journalists so that they could discuss much on other issues of media development.

\section{Observation}

In total there were 273 cases recorded as the violation of press freedom in the annual report of IFJ from May 2007 to April 2015. Taking the manual published by UNESCO and FNJ as reference, all the cases were categorized on relevant category. The manual has determined the following nine cases/events as the violation of press freedom.

- Death: Targeted Killing, Suspicious killing, Accidental Death.

- Arrest: Arbitrary arrest, Custody, Jailed, Held for some time, Tortured.

- Missing: Unknown whereabouts, Enforced disappearance, Abduction.

- Seizure: Confiscation, Robbery, Taken under control, Obstruction, Obstruction to distribution of products.

- Attack: Attempt to murder, Impair, Injury and fatal injury, Arson.

- Gender Violence: Rape, Attempt to rape, Sexual Harassment.

- Threat: Threat to life, Threat to Limb, Psychological threat, Threat to be displaced from the job, Slander.

- Displacement: Threat to be displaced from the workplace.

- Professional insecurity: Deprived from employment, Deprived from minimum wages, Deprived of duty.

While building the dataset, the complete information of victim was not available and even the information of the event was inadequate. Lack of such basic information limits our understanding on the press freedom violation issue. This section initially provides the summary of the cases of Press Freedom violation and then will talk about the underlying issues over the overall approach of the report.

\subsection{Number of Press Freedom Violation}

The graph below represents the total number of cases in each year. The number of cases of Press Freedom violation recorded the highest in the year 2008/2009 while the same case was declined drastically in 2013/14. After that, the case was plateau (Figure 1).

\subsection{Cases of Press Freedom Violation}

The two tables below present the number of cases of press freedom violation during the period of study. The first is pie chart representing the total cases. The second one is a chart with cases in each year. Arrest of the journalist was the 
most prominent case of press freedom violation followed by threats on them (Figure 2 \& Figure 3).

The overall observation of the cases gives the impression that whether all the categories of Journalists mentioned in Code of Ethics 2003 (amended 2008) are

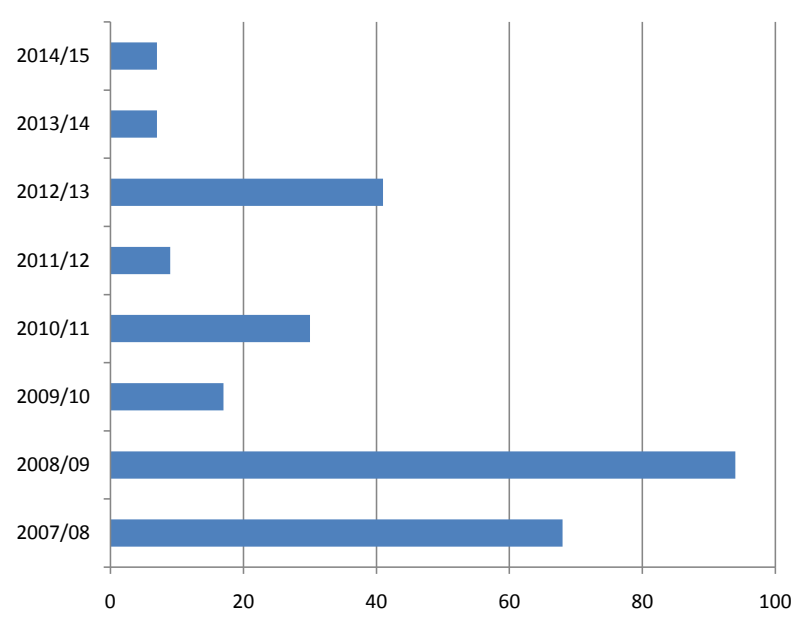

Figure 1. Number of Press Freedom violation. Source: IFJ annual report.

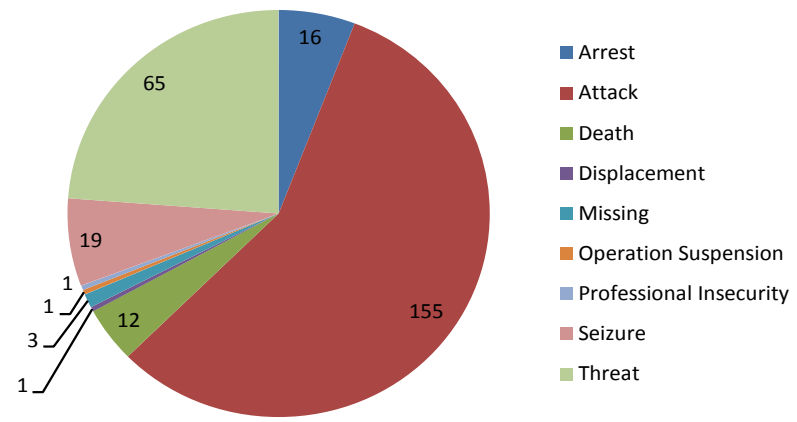

Figure 2. Cases of Press Freedom Violation. Source: IFJ annual report.

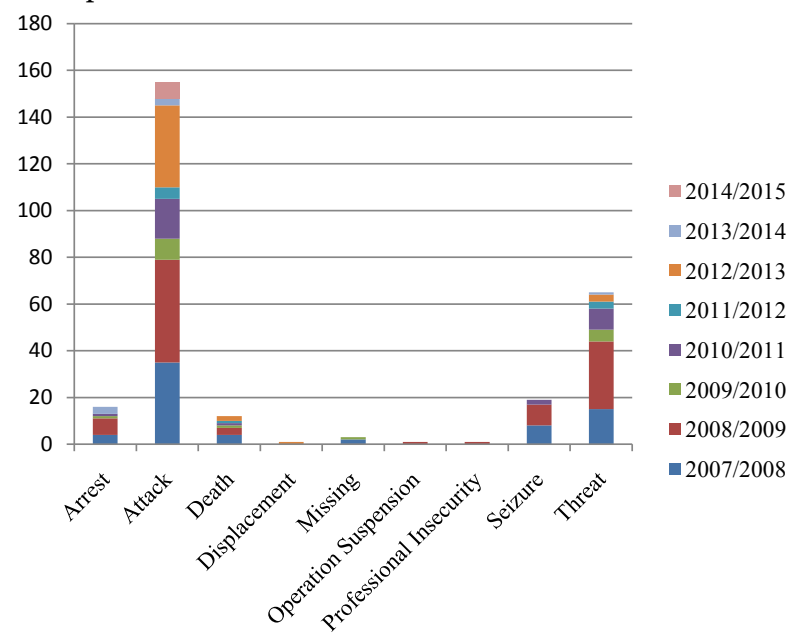

Figure 3. Cases of Press Freedom Violation (yearly basis) Source: IFJ annual report. 
entitled for equal privilege or there needs to be $s$ distinction between the journalists/reporter and technical staffs of the media house. Should the journalist be given same preference as the media owners and other supporting staffs of media organizations or there should be any distinction? From the information provided, there is not a strong point to say if those events occurred merely while performing the job or there are some other causes over such attacks or threats. There is no clear indication that whether the attacks and threat are the consequences of what the journalist wrote. These reports/cases are much concerned with the personal safety of journalist where as the issues of professional safety for example appointment letter, minimum wages, regular payment of salary/wages are much discussed and debated after the peace agreement of 2006. Similarly, the influence of corporate sector in newsroom which is promising issue even in the global context seems to be ignored in these reports. Not a single case of sexual violence against women in these reports. But other researchers have mentioned the issue of sexual violence. Rather than focusing just on the events of press freedom violation, an in-depth report underlying the causes and context of the event will help us make the journalism sector free from pressure and will enjoy freedom as envisioned in the constitution.

There is not a clear provision where to report the cases of Press Freedom Violation. However, the issues related to threat on journalist's personal life could be reported to the police. But surprisingly very few cases of alleged Press Freedom violation were reported to police. As the case show they are based on the claims made by the victims (journalists, media owners, organization), there comes an issue of reliability as even the Journalists are highly polarized based on their political affiliation. Is just making a claim that someone is victimized is sufficient or there needs to be an investigation over such claim and the underlying issues? Moreover, there are cases where the journalist associations had exerted pressure on police and government for just arrest to journalist for alleged illegal cases. Neither journalist association has taken any action to its members involved in unethical things like bribery; blackmailing nor it has supported investigation from authority. In contrast, they rush to release a statement claiming press freedom violation without going deep on the event.

A much detail of the few cases reflecting the shortcomings in the report are described below as the case studies.

The research shows that ownership widely affects the issues of advertising especially when concerned media itself becomes a news event (Prajapati, 2012).

\section{Case Studies}

\section{Case 1:}

The murder case of journalist Uma Singh was quite significantly discussed and controversial issue. This case reflects how the issue of press freedom is manipulated to get political benefit.

11 January 2009: Journalist and human rights activist Uma Singh, 26, was murdered in the town of Janakpur by a gang of about 15 men after she returned 
home from work. Singh, a correspondent for the Janakpur Today daily and the radio station of the same name was stabbed repeatedly on the verandah that her dwelling shares with three others (IFJ Report 2008-09).

There are two distinct reports regarding the murder of Uma Singh. No doubt she was murdered but for what reason she was murdered is important. Organizations like CPJ, IFJ, FNJ argued that her murder is related to her job. The IFJ concludes there are strong links between Uma Singh's murder and her professional work as a journalist in investigating the wrongful expropriation of land during Nepal's decade-long insurgency (Park \& Aidan, 2009). One of the arguments in the report to relate this murder with the job is a report where she mentioned: "The Maoists have not returned the seized land in Siraha district even three months after Maoist chairman and Prime Minister Pushpa Kamal Dahal directed his party cadres to do so. Some 1,200 bigahas of land captured during the People's War is still under Maoist control." The affiliation of the mastermind of the murder Umesh Yadav with Maoist party is not sufficient to confirm that he murdered Uma Singh for the above mentioned report. But Shah (2010) mentions quoting the police officer that the murder was related with the property issue within the family. After 15 days of the murder of Uma Singh, her mother filed a case at Local Police Office where she had not mentioned that her murder was related to her journalistic job. Shah (2010) confirms that it is not true that the immediate blame to Maoist party responsible for her murder due to her journalistic job. There might be an involvement of any Maoist activist/cadre but this seems just due to personal relation and selfishness. The Prime Minister and Chairman of UCPN (Maoist) party had also denied his parties involvement for the murder. He said "the Maoist party can't be blamed for the murder of journalist Singh just on the basis that her (Uma Singh's) father and brother were abducted and disappeared by Maoist cadres in the past" with the team of FNJ (Online newsportal).

Case 2:

The case on how failing to obey journalist code of conduct affects Press Freedom could be demonstrated by the following case.

28 May 2010: Pro-Maoist demonstrators burnt copies of the Nagarik and Republica dailies in Kathmandu, after they published stories alleging Maoists had kidnapped a hospital director. Maoists also disrupted newspaper distribution in sections of the country, according to their publishers (IFJ Report 2010-11).

There is no doubt this disruption was an event against press freedom. But it is equally important that whether the newspaper or journalists are following the code of conduct. Even though the news confirmed to be biased and untrue, the newspaper hasn't yet felt the necessity to apologize for the wrong news. This shows even the big media houses are not following the ethics and try to bring issue of press freedom in order to cover their own shortcomings and faults. Hence, the issue of press freedom brings all aspects of media business rather 
than an absolute value of press freedom.

\section{Case 3:}

The following case shows how the issue of Press Freedom is understood in our context.

10 March 2011: Chairman of National Television Nepal Yunus Ansari was shot and injured in the central jail in Sundhara (IFJ Report 2010-11)

Though Yunus Ansari was shot and injured in the central jail, the reason behind this shooting was not related to any journalistic profession. Neither he was performing any journalistic duty nor was he shot for being the chairman of a television station. Of course, we can argue about the charge against him. However, if we claim such cases as Press Freedom Violation, this will definitely not help to institutionalize media industry and make it professional. Yunus Ansari, was arrested for his suspected involvement in drug trafficking and fake Indian currency racket (Ghimire, 2011).

Press Freedom and rights of journalists are not separate issues. Exploiting employees to run a media can never be the right of media owner. But the concern is over the advocacy of press freedom without the right of the journalists or employees in the media houses. There is no point to disagree with the view of Acharya (2010) that the disruption of distribution and dissemination of press materials is attacks on press freedom but if an employee demands job security and a fair salary assured through an act, it can never be related to attacks on press freedom.

The above cases lead to raise a question whether the lack of detail information while recording the various issues of press freedom violation might be to deviate from the actual case of other business of journalists. This question is supported from the conclusion of Paudel (2015) that as majority of the journalists are affiliated with political parties, it is difficult to distinguish the threats and identify whether they are due to their news coverage or for some reason.

Despite the growth of online media every year, laws related to online media are yet to be made. A number of journalists were arrested for either publishing or sharing the news in their online portal or sharing in their facebook profile. Such cases related to online media are dealt under the provision of Electronic Transition Act which is inappropriate. The issues related to online media should be dealt with an appropriate law/act instead of Electronic Transition Act.

\section{Conclusion}

Though it is claimed journalists are being physically assaulted and threatened just for writing news reports, this study doesn't get sufficient information to confirm the argument. Very few cases of press freedom violation seem as consequences of the news reports. Unlike the perception that journalists are harassed and attacked for writing or speaking, journalists undertaking investigative stories haven't been even questioned for the accuracy of the facts in the report. It has been traced that those investigative reportings were on serious corruption, 
political gains, misuse of resources, and abuse of authority with clear names of the people involved.

The finding shows physical safeties of journalists, especially attack and threat are the major issues in Press Freedom since the signing of Peace Agreement on 2006. Non-state actors especially the political parties are seen being involved in larger number of attacks on press freedom. The direct affiliation of journalists as a member of political party and the intolerance of political party members for criticism might be the responsible for this. But it is difficult to conclude whether the journalists were performing their duty or involved in political protests when they were attacked.

Despite the liberal constitutional provisions regarding media, the press doesn't seem to be free from criticism. Revision of the established way of framing the issues related to working journalists and media organizations might lead to a reliable dataset which make various actors responsible that ultimately ensures press freedom. Further discussions on the ethical issues of journalists and media houses, implementation of various laws related to media and journalists will assist to ensure the Press Freedom.

To sum up, rather than framing every event related with journalists and media houses, as the violation of press freedom, performing the journalistic duty honestly will make journalist more professional and dignify which ultimately fosters media sector. Apart from other institutional provisions, the review of Minimum Wages provision and its strict implementation will help journalists become much responsible towards their job. This will ultimately improve the press freedom situation and help institutionalize the media sector.

\section{References}

The Economic Weekly. (1955). Nepal-China Relations.

United Nations Educational, Scientific and Cultural Organization (UNESCO). (2013). Assessment of Media Development in Nepal.

Acharya, S. (2010). Working Journalist Act and Press Freedom. In Let Live and Write, Ed., Press Freedom Annual Report 2010, Dewan Rai. Kathmandu: Federation of Nepali Journalists.

Adhikari, D. (2008). Democracy Can Complicate the Job of Journalists. 21st Century Muckrakers Who Are They? How Do They Do Their Work? Nieman Reports, 62, 79-81.

Banjade, A. (2007). Community Radio in Nepal: A Case Study of Community Radio Madanpokhara in Western Nepal. Athens: Ohio University.

Baral, L. R. (1975). The Press in Nepal 1951-1974. Contribution to Nepalese Studies, 169-186.

Becker, L. B., Vlad, T., \& Nusser, N. (2007). An Evaluation of Press Freedom Indicators. International Communication Gazette, 69, 5-28.

Belbase, S. and Murphy, J. E. (1983). Press Performance in Nepal during Two Political Climates. Journalism Quarterly, 60, 61-66.

Bhattarai, K. D. (2013). Despite Odds Women Doing Good in Journalism. The Kath- 
mandu Post.

Dahal, K. R. (2011). Mass Media and Law. Kathmandu: Nepal Press Institute.

Dahal, S. P. (2013). Nepalese Journalists' Democracy Building Roles and News Coverage Practices. Bodhi: An Interdisciplinary Journal, 6, 65-108.

https://doi.org/10.3126/bodhi.v6i0.9246

Dahal, T. (2006). Impact and Trend. In K. Chapagain (Ed.), Nepalese Media: Under Royal Regime. Kathmandu: Federation of Nepalese Journalists.

Devkota, G. B. (2002). Nepal Ko Chapakhana Ra PatrapatrikoItihas (History of Printing Press and Journalism of Nepal) (3rd ed.). Kathmandu: Shanja Prakashan.

Gaunle, S. (2006). Journalism under Royal Regime. In K. Chapagain (Ed.), Nepalese Media under Royal Regime. Kathmandu: Federation of Nepalese Journalists.

Gautam, B. (2008). Press Swatantratako Byabasikra Rajnitik Sandharva (Professional and Political Context of Press Freedom). In D. Humagain, P. Onta, S. Parajuli, \& K. Bhatta (Eds.), Media Adhyayan 3. Kathmandu: Martin Chautari.

Ghimire, Y. (2011). Jailed Nepal TV Chief Shot at by "Hitman" from India. In The Indian Express. Online Edition. New Delhi.

Himelboim, I., \& Yehiel, L. (2008). Media Perception of Freedom of the Press a Comparative International Analysis of 242 Codes of Ethics. Journalism, 9, 235-265. https://doi.org/10.1177/1464884907089007

Bhuwan, K. C. (2014). Political Inclination of Journalists \& It's Influence on News. In Master Project of Master of Journalism. Manila: Ateneo de Manila University.

Kafle, C. (2003). Nepali Press during State of Emergency (Maiden ed.). Kathmandu: Federation of Nepalese Journalists.

Karlekar, K. D., \& Marchant, E. (2007). Freedom of the Press 2007: A Global Survey of Media Independence. Freedom House.

Mainali, R. (2006). Raja Gyanendrako Sashankalra Sancharmadhyam ma Censorship. [King Gyanendras Rule and Censorship in Media.] In D. Humagain, P. Onta, S. Parajuli, K. Bhatta, \& K. Adhikari (Eds.), Media Adhyayan 1. Kathmandu: Martin Chautari.

Neupane, D., \& Li, Z. (2014). Condition of Nepali Journalists after the 2008 Constituent Assembly Election. Journal of International Communication, 20, 87-97. https://doi.org/10.1080/13216597.2014.880362

Onta, P. (2001). The Print Media in Nepal since 1990: Impressive Growth and Institutional Challenges. Studies in Nepali History and Society, 6, 331-346.

Onta, P. (2006). Mass Media in Nepal Post-1990 Nepal. Kathmandu: Martin Chautari.

Parajuli, L. (2012). Objectionable Contents': The Policing of the Nepali Print Media during the 1950s. European Bulletin of Himalayan Research, 41, 58-83.

Park, J., \& Aidan, W. (2009). Capsule Report: Nepal. International Federation of Journalists.

Pathak, T. (2006). Impact of Political Affiliation in Writing in Weekly Papers. Kathmandu: Unpublished Master's Thesis. Tribhuwan University.

Paudel, B. K. (2015). Country Report Nepal. In R. Ottosen, \& M. Høiby (Eds.), Journalism under Pressure: A Mapping of Editorial Policies and Practices for Journalists Covering Conflict. Oslo: Oslo and Akershus University College of Applied Sciences.

Prajapati, U. (2012). Safeguarding Public Interest in the Era of Corporate Media. Policy 2012. 
Kharel, P. (2012). Media for Participatory Democracy Kathmandu. Kathmandu: Supravaha Publication (P.) Ltd.

Shah, T. (2010). Mithilako Patrakarita ma Dwandaka Karanharu. [Reasons for the Conflict in Journalism of Mithila.] In D. Humagain, S. Parajuli, \& P. Onta (Eds.), Media Adhyayan 5. Kathmandu: Martin Chautari.

Siebert, F. S., Peterson, T., \& Schramm, W. (1963). Four Theories of the Press. Urbana University of Illinois Press. 